\title{
Aplikasi E-Learning Al-Islam Kemuhammadiyahan pada STMIK Muhammadiyah Jakarta
}

\author{
Hairil Kurniadi Siradjuddin ${ }^{1}$, Eko Saputra Ismail ${ }^{2}$, Nova Lailia Ahsanti ${ }^{3}$ \\ Program Studi Teknik Informatika, Fakultas Teknik, Universitas Khairun \\ Jl. Jati Metro, Kota Ternate Selatan \\ E-mail : hairil.kurniadi@unkhair.ac.id ${ }^{1}, \underline{\text { ekoismai104@gmail.com² }}$, novalailia01@ gmail.com³
}

\begin{abstract}
E-learning can be interpreted as an Online learning system, where the application of the website provides learning data and information that can be accessed by students or students, without having to meet face to face with the instructor, therefore we intend to design and build an E learning system. -Learning AlIslam and Kemuhammadiyahan at STMIK Muhammadiyah Jakarta, which during this time we assume that the lecture system is not maximal. The purpose of writing the Final Task of Al-Islam Compres is to build an Online learning system (Elearning) that is centralized and integrated into a system information based on Moodle's webisite CMS (Content Management System), to help students studying at STMIK Muhammadiyah Jakarta in the lecture process and to make it easier to obtain material and information related to Alllam and Kemuhammadiyahan courses, in making this system we use library research methods and meto de design, for library research methods we collect data and information about lecture material and STMIKMJ students and lecturers while our design method develops a Moodle CMS application system to support the Elearnig learning process, it can be concluded that the existence of this application can facilitate students to access Information and lecture material and lecturers are easier to carry out the lecture process at STMIK Muhammadiyah Jakarta.
\end{abstract}

\section{Keywords; E-learning, Al-Islam and Kemuhammadiyahan. Stmik Muhammadiyah Jakarta}

Abstrak, E-learning dapat diartikan sebagai sistem pembelajaran Online,dimana aplikasi website tersebut menyediakan data dan informasi pembelajaran yang bisa diakses oleh pelajar atau mahasiswa,tanpa harus bertatap muka dengan pengajar,oleh karena itu kami bermaksud untuk merancang dan membangun sebuah sistem pembelajaran E-learning Al-Islam dan Kemuhammadiyahan di STMIK Muhammadiyah Jakarta,yang selama ini kami mengganggap bahwa sistem perkuliahannya belum maksimal.Maksud dari penulisan Tugas Akhir Kompre Al-Islam ini adalah untuk membangun sebuah sistem pembelajaran Online (Elearning) yang terpusat dan terintegrasi kedalam sebuah sistem informasi berbasis webisite CMS (Content Manajemen System) Moodle,untuk membantu mahasiswa yang kuliah di STMIK Muhammadiyah Jakarta dalam proses perkuliahan serta mempermudah dalam mendapatkan materi dan Informasi yang berkaitan dengan mata kuliah AIIslam dan Kemuhammadiyahan,dalam pembuatan system ini kami menggunakan metode riset pustaka dan metode perancangan,untuk metode riset pustaka kami mengumpulkan data dan informasi tentang materi perkuliahan serta mahasiswa dan dosen STMIKMJ sedangkan metode perancangan kami mengembangkan sebuah sistem aplikasi CMS Moodle untuk menunjang proses pembelajaran Elearnig tersebut,dapat disimpulkan bahwa dengan adanya aplikasi ini dapat mempermudah mahasiswa untuk mengakses Informasi dan materi perkuliahan serta dosen lebih mudah dalam melaksanakan proses perkuliahan di STMIK Muhammadiyah Jakarta.

Kata kunci ; E-learning, AlIslam dan Kemuhammadiyahan, Stmik Muhammadiyah Jakarta

\section{PENDAhuluan}

\subsection{Latar Belakang}

Ditengah perkembangan teknologi informasi yang sangat pesat,kebutuhan akan informasi yang akurat,tepat dan relevan, sangat dibutuhkan untuk memberikan kemudahan dan keberhasilan dalam pengolahan data dan penyediaan informasi yang dibutuhkan.

Internet merupakan salahsatu sistem teknologi informasi yang mengalami peningkatan cukup signifikan,karena proses pengolahan dan penyediaan informasi dapat diakses dengan cerpat serta memiliki keakuratan informasi yang bisa dipertanggungjawabkan,hal ini bisa dilihat dari semakin meningkatnya pengguna internet di seluruh dunia.

E-learning dapat diartikan sebagai sistem pembelajaran Online,dimana aplikasi website tersebut menyediakan data dan informasi pembelajaran yang bisa diakses oleh pelajar atau mahasiswa,tanpa harus bertatap muka dengan pengajar,oleh karena itu kami bermaksud untuk merancang dan membangun sebuah sistem pembelajaran E-learning Al-Islam dan Kemuhammadiyahan di STMIK Muhammadiyah Jakarta,yang selama ini kami mengganggap bahwa sistem perkuliahannya belum maksimal,sehingga dengan adanya aplikasi E-learning ini dapat membantu dosen dan mahasiswa dalam proses perkuliahan,serta kemudahan bagi mahasiswa untuk mendapatkan 
informasi dan materi.keunggulan yang ditawarkan dalam sistem ini adalah tidak terlalu mahal dalam proses perancangannya karena menggunakan aplikasi gratis (open source),kecepatan informasi dan tidak membutuhkan proses perkuliahan didalam kelas,mahasiswa cukup mengakses aplikasi tersebut lewat internet kita sudah bisa berinteraksi layaknya perkuliahan di kelas,aplikasi ini juga menyediakan,materi,kuis ,ujian serta penilaian yang dirancang secara otomatis,sehingga bisa menghasilkan sebuah metode pembelajaran yang efektif dan efesien serta berkualitas.

\subsection{Perumusan Masalah.}

Bagaimana Merancang sebuah system Pembelajaran berbasis Online menggunakan aplikasi CMS Moodle 2,0, pada Kampus STMIK Muhammadiyah Jakarta

\section{TINJAUAN PUSTAKA}

\subsection{Pengertian E-Learning.}

E-learning merupakan singkatan dari Elektronic Learning, merupakan cara baru dalam proses belajar mengajar yang menggunakan media elektronik khususnya internet sebagai sistem pembelajarannya. E-learning merupakan dasar dan konsekuensi logis dari perkembangan teknologi informasi dan komunikasi.

Beberapa ahli mencoba menguraikan pengertian e-learning menurut versinya masingmasing, diantaranya:

Jaya Kumar C. Koran (2002) e-learning sebagai sembarang pengajaran dan pembelajaran yang menggunakan rangkaian elektronik (LAN, WAN, atau internet) untuk menyampaikan isi pembelajaran, interaksi, atau bimbingan.

Dong (dalam Kamarga, 2002) e-learning sebagai kegiatan belajar asynchronous melalui perangkat elektronik komputer yang memperoleh bahan belajar yang sesuai dengan kebutuhannya..

\subsection{Pengertian PHP.}

PHP adalah salah satu bahasa pemrogaman web yang open source, kode PHP dapat digabungkan dengan kode HTML untuk membentuk suatu halaman web yang dinamis, dalam konsep web, jika suatu web browser mengakses file dengan kode HTML murni maka web server akan mengirimkan file terakses secara utuh tanpa ada proses terlebih dahulu terhadap kodekode yang digunakan dalam file tersebut, berbeda dengan file PHP, web server akan mengirimkan file PHP tersebut ke suatu program kompiler (dalam hal ini adalah PHP kompiler) untuk segera diproses, PHP compiler tersebut akan mengirimkan hasil prosesnya ke web server untuk segera dikirimkan kembali ke program pengakses. Hal ini akan memudahkan pembuat website untuk mengembangkan website dinamis, dalam hal ini website yang dapat merespon apa yang diminta oleh masing-masing program pengakses.

\subsection{Pengertian MySQL.}

MySQL adalah sebuah perangkat lunak sistem manajemen basis data SQL (bahasa Inggris: database management system) atau DBMS yang multithread, multi-user, dengan sekitar 6 juta instalasi di seluruh dunia. MySQL AB membuat MySQL tersedia sebagai perangkat lunak gratis dibawah lisensi GNU General Public License (GPL), tetapi mereka juga menjual dibawah lisensi komersial untuk kasus-kasus dimana penggunaannya tidak cocok dengan penggunaan GPL.

\subsection{Perangkat Keras dan Lunak Yang dibutuhkan.}

1. Perangkat Lunak

a) Windows XP,sebagai sistem Operasi yang sudah lazim dipakai,yang memiliki performansi yang bagus dan kompatibel.

b) MySQL 4.1.9. sebagai database server yang ringan dalam mengeksekusi query.

c) PHP 5.0.3.sebagai bahasa pemrograman berbasis web yang mudah dipelajari.

d) Aplikasi Open Source Moodle 2.2 sebagai software untuk membangun aplikasi ELearning.

e) XAMPP, untuk membantu pembuatan aplikasi secara Offline/localhost.

2. Perangkat Keras

a) Processor Intel Pentium Core 2 Duo 2,84 GHz.

b) Memory $2 \mathrm{~GB}$

c) PCI VGA $512 \mathrm{MB}$

d) Harddisk $500 \mathrm{~GB}$

\subsection{Al Islam Kemuhammadiyahan.}

Muhammadiyah memulai gerakannya dengan menempatkan pendidikan sebagai salahsatu ujung tombak kiprah dakwahnya. Bahkan dapat dikatakan pendidikan sebagai kekuatan yang menentukan berkembangnya Muhammadiyah. Kekuatan itu bukan terletak dari model sekolah atau madarasah yang didirikannya,melainkan dengan kekuatan pada ruh dan pemahaman Islam dalam pendidikan Muhammadiyah. Selanjutnya pemahaman tersebut dibenahi dengan sebutan Al-Islam dan Kemuhammadiyahan. Adapun bagian integral dari kemuhammadiyahan sendiri mencakup berbagai pokok materri,diantaranya pengertian,maksud,tujuan dan ruang lingkup.

\subsection{Aplikasi MOODLE 2.2.}

Aplikasi Moodle (Modular Object-Oriented Dynamic Learning Environment) dikembangkan pertama kali oleh Martin Dougiamas pada Agustus 2002 dengan Moodle Versi 1.0. Dougiamas membuat Moodle hanya untuk hobi, walaupun di akhir kisah, dia juga menjadikan hobi itu sebagai tesis untuk mendapatkan gelar $\mathrm{PhD}$ dari Curtin University of Technology di Perth, Australia.

Dedikasi, inovasi, dan kontribusi untuk open source dari software Moodle memang fenomenal. Moodle hingga kini masih memimpin sebagai software gratis untuk membangun website komunitas yang mendukung proses pembelajaran berbasis website.

Prinsip pedagogi dipegang teguh Moodle karena membantu pendidik menciptakan komunitas pendidikan online. Software ini bisa digunakan guru 
atau institusi pendidikan. Juga potensial digunakan perseorangan untuk membangun kursus online.

Hingga Januari 2008, jumlah website yang menggunakan Moodle tercatat 38.896 website (yang resmi terdaftar) dan digunakan 16.927 .590 pengguna dengan jumlah materi 1.713.438 buah.

\section{METODLOGI PENELITIAN}

\subsection{Metode Perancangan Sistem.}

Metode protyping sebagai suatu paradigma baru dalam pengembangan sistem informasi, tidak hanya sekedar suatu evolusi dari metode pengembangan sistem informasi yang sudah ada, tetapi sekaligus merupakan revolusi dalam pengembangan sistem informasi manajemen.

Tahapan yang digunakan dalam metodologi prototype adalah antara lain :

a) Mengidentifikasi Kebutuhan Pemakai.

b) Mengembangkan Prototype

c) Menentukan apakah prototype dapat diterima atau tidak

d) Menggunakan Prototype

\section{HASIL DAN PEMBAHASAN}

\subsection{Gambaran Umum Program.}

Aplikasi E-learning Al-Islam dan Kemuhammadiyahan pada STMIK Muhammadiyah Jakarta menggunakan CMS MOODLE adalah aplikasi belajar online yang dibuat untuk membantu para mahasiswa untuk mendapatkan materi tanpa harus nertatap muka di ruang kuliah,aplikasi ini jjuga menyediakan informasi tentang materi kuliah,nilai serta berisikan test dan ujian bagi para mahasiswa, yang dirancang secara otomatis,sehingga bisa menghasilkan sebuah metode pembelajaran yang efektif dan efesien serta berkualitas.aplikasi ini juga sangat bermanfaat bagi dosen dalam melakukan proses perkuliahan,dimana dosen hanya menyediakan materi didalam aplikasi ini tanpa harus bertatap muka didepan kelas.

\subsection{Pembuatan Aplikasi E-Learning..}

Berikut ini adalah cara pembuatan aplikasi elearning dengan menggnnakan CMS Moodle.

Menyiapkan software yang dibutuhkan yaitu :

a) XAMPP

b) CMS Moodle

Proses Instalasi dan Pembuatan aplikasi :

a) Instalasi Xampp (apache web server),sebagai software pendukung untuk pembuatan aplikasi e-learning secara offline (localhost) Langkah selanjutnya,cukup dengan menekan tombol Next sampai prosese instalasi selesai.

b) Instalasi Software CMS Moodle,yang merupakan aplikasi yang digunakan untuk membangun sistem pembelajaran online, dengan cara mengestrak file Moodle ke dalam C/xampp/htdoc,stelah itu bukalah web browser (mozila firefox),dan buat database baru,keudian ketik localhost/moodle pada url maka akan tampil gambar sebagai berikut:

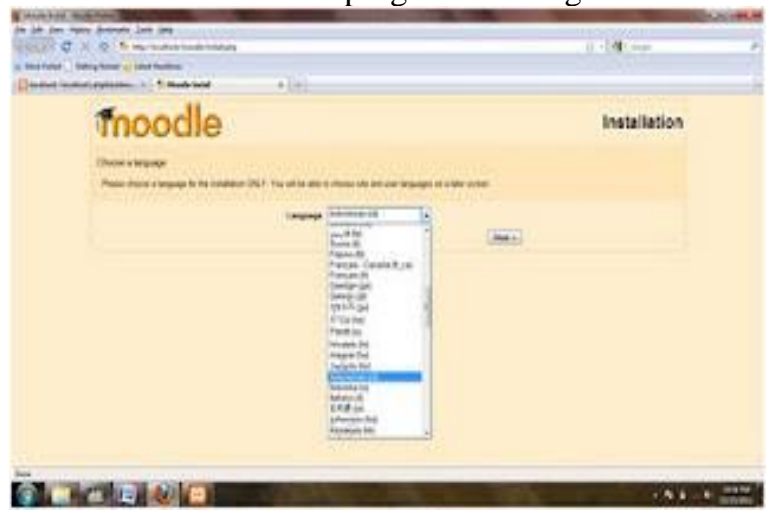

Gambar 3.2. Proses Instalasi Moodle

Langkah selanjutnya cukup dengan mengikuti petunjuk instalasi sampai proses intalasi selesai.

Berikut gambar setelah selesai proses instalasi CMS Moodle (tampilan awal halaman E-learning):

c) Pengaturan halaman utama aplikasi e-learning mulai dari tampilan sebelum login dan sesudah login seperti thema,judul aplikasi,bahasa sampai hak akses.

d) Pembuatan kategori kursus,materi dan kuis untuk kepentingan pembelajran e-learning.

e) Pembuatan User baru sesuai dengan kebutuhan,kita dapat membuat user baru satu persatu ataupun membuat sekaligus dalam jumlah yang banyak dengan cara upload file.

\subsection{Tahapan Perancangan Sistem.}

Tahapan-tahapan dalam pengembangan sistem nmneggunakan metode prototype adalah sebagai berikut:

\subsubsection{Identifikasi Kebutuhan User.}

Tahapan mengidentifikasi kebutuhan pemakai,dapat dilakukan dengan membuat sebuah kuesioner untuk mengetahui keinginan dari user yang merupakan mahasiswa di lingkungan Kampus STMIK Muhammadiyah Jakarta tentang aplikasi yang akan dibuat.

\subsubsection{Mengembangkan Prototype.}

Tahapan selanjutnya adalah mengembangkan prototype . pada tahapam ini dilakukan dengan cara membuat alur program/aplikasi yang akan dibuat, membuat konsep dari program yang akan dibangun serta pembuatan struktur navigasi, desain tampilan, pengumpulan data dan materi pemrograman.

\subsection{Konsep Pengembangan.}

Tahapan pertama dalam pengembangan adalah pengajuan konsep yang didalamnya adalah menentukan arah dan tujuan program/aplikasi yang akan dibangun.

\subsubsection{Struktur Navigasi Program/Aplikasi}




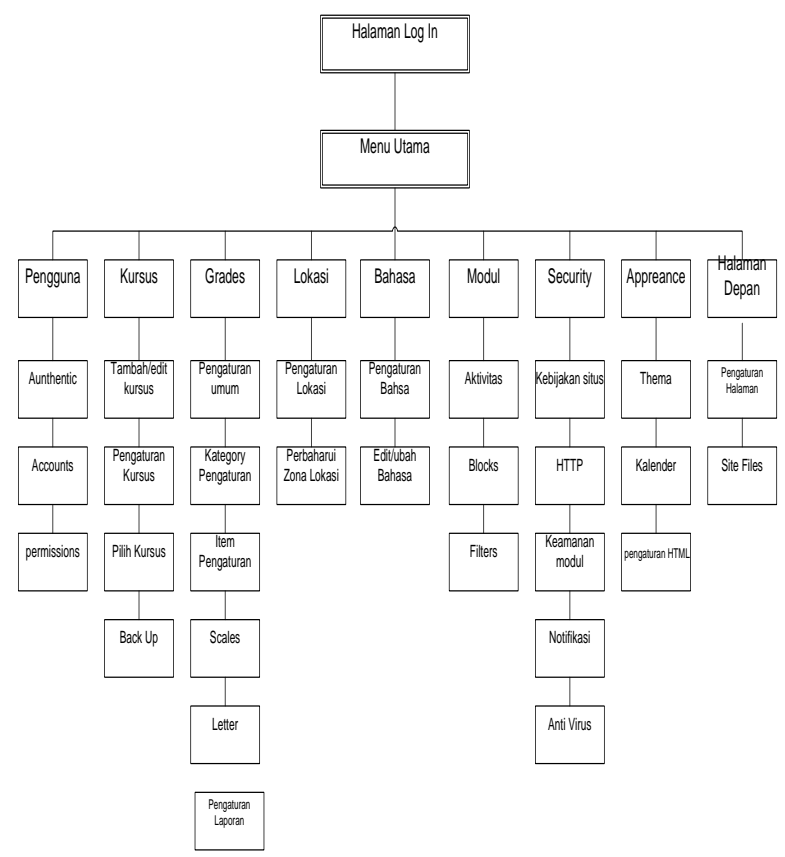

Gambar 3.5. Struktur Navigasi.

\subsubsection{Prototype dapat diterima atau tidak.}

Untuk lebih jelasnya diperlukan beberapa pertanyaan kepada pengguna untuk mengetahui keunggulan dan kelemahan dari aplikasi yang dibuat, hasil dari pertanyaan tersebut dapat dilihat pada tabel dibawah ini :

Tabel 3.2 Daftar Pertanyaan Quesioner

\begin{tabular}{|c|l|c|c|}
\hline N & \multicolumn{2}{|c|}{ Jenis Pertanyaan } & \multicolumn{2}{|c|}{ Hasil } \\
\cline { 2 - 4 } O & \multicolumn{1}{|c|}{ Ya } & Tidak \\
\hline 1. & $\begin{array}{l}\text { Apakah tampilan dari } \\
\text { aplikasi yang dibuat } \\
\text { disukai oleh pengguna? }\end{array}$ & $\checkmark$ & \\
\hline 2. & $\begin{array}{l}\text { Apakah diperlukan } \\
\text { penambahan terhadap } \\
\text { menu dan navigasi dari } \\
\text { aplikasi? }\end{array}$ & $\checkmark$ & \\
\hline 3. & $\begin{array}{l}\text { Apakah diperlukan } \\
\text { update materi kuliah } \\
\text { setiap hari atau setiap } \\
\text { minggu? }\end{array}$ & $\checkmark$ & \\
\hline 4. & $\begin{array}{l}\text { Apkah aplikasi ini bisa } \\
\text { mengatasi kesilitan } \\
\text { dalam perkuliahan? }\end{array}$ & $\checkmark$ & \\
\hline
\end{tabular}

\subsubsection{Menggunakan Prototype.}

Tahapan terakhir dari prototype adalah aplikasi yang tadinya sudah di uji dan diperbaiki siap untuk digunakan oleh pengguna, berikut cara penggunaan dari aplikasi Elearning Alislam dan Kemuhammadiyahan.

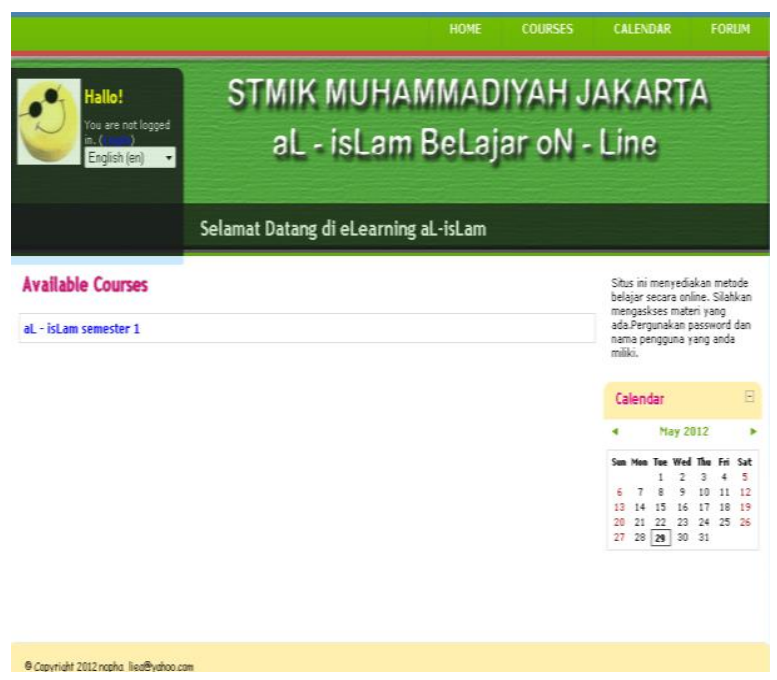

Gambar 3.10. Tampilan Awal Aplikasi

4.5 Cara Penggunaan Aplikasi.

Tahapan berikut adalah tuntunan dalam menggunakan Aplikasi Elearning secara Offline, yang diantaranya adalah sebagai berikut :

1) Aktifkan Local server Xammp ( dengan cara mengaktifkan tombol apache dan Mysql ).

2) Jalankan Web Browser ( Mozilla Firefox, Opera dan IE)

3) Ketikkan nama URL aplikasi ; http://localhost/Alislam kemudian tekan enter, maka akan tampil halaman awal dari aplikasi seperti dibawah ini :

Langkah selanjutnya adalah pengguna harus melakukan proses Log In untuk bisa mengakses pada menu utama dengan cara :

1) Tekan tombol Log In pada pojok kanan atas halam awal

2) Setelah muncul halaman Log In, masukkan Nama dan Password dari pengguna kemudian tekan tombol Log In, secara otomatis akan diarahkan ke halaman menu utama

Selanjutnya pengguna dapat mengakses seluruh isi halaman sesuai dengan keinginannya seperti

\section{Untuk Admin}

a) Membuat kursus,

b) Membuat kuis,

c) Mengelola nilai,

d) Mengganti thema,

e) Menambah atau memperbaharui pengguna/user

Untuk Mahasiswa /pengguna

a) Mendaftarkan diri untuk mengikuti kursus.

b) Mengambil/mengunduh materi.

c) Mengikuti tes dan Kuiss

d) Mengecek Nilai

\section{KESIMPULAN}

1) Aplikasi dapat digunakan oleh seluruh mahasiswa STMIK Muhammadiyah Jakarta pada umumnya sebagai media pembelajaran 
interaktif, selain materi yang siberikan dalam tatap muka di ruang kuliah.

2) Aplikasi ini dapat digunakan dimanapun dan kapanpun disesuaikan dengan kondisi, dimana bisa digunakan secara offline dengan memanfaatkan LAN ( Local Area Network ), ataupun dengan cara On line memanfaatkan teknologi internet.

3) Metodologi yang digunakan dalam pembuatan aplikasi ini adalah metode prototype , karena melibatkan pengguna dalam perancangan tampilan interface dan isi content.

\section{DAFTAR PUSTAKA}

[1] Herlambang soendoro \& tanuwijaya heryanto,system informasi;konsep teknologi \& manajemen,2005 hal. 188
[2]. Raymond Mcleod Jr,system informasi manajemen,edisi 7;2001; hal 211

[3]. http://yanazmi.blogspot.com/2009/04/pengertianaplikasi.html (aplikasi)

[4]. http : //www.id.wikipedia.org/wiki/aplikasi

[5]. http : //www.total.or.id/info.php?kk=application

[6]. http://e-

dufiesta.blogspot.com/2008/06/pengertian-elearning.html

[7]. http://amiroh.web.id/menambahkan-chattingdalam-moodle/

[8]. http://edufiesta.blogspot.com/2008/06/pengertian-elearning.html

[9].http://idam2010.wordpress.com/2010/03/30/penger tianprototype/ (prototype)

[10]. http://yuliagroups.wordpress.com/pengertianprotot 